Gesant van die mispels en In die stille agterkamer bevat ekfrastiese gedigte wat geïnspireer is deur 12 en 14 skilderye van onderskeidelik die Nederlandse skilders Adriaen Coorte en Jan Mankes. Telkens word die Afrikaanse gedigte vergesel deur Nederlandse vertalings van Henda Strydom en Van Niekerk.

Die Afrikaanse poësie ken verskeie ekfrastiese gedigte—dikwels bepeinsende reaksies op en inlewings in visuele kunswerke. Hier dink'n mens aan gedigte van Johan van Wyk, Johann de Lange, Antjie Krog en Fourie Botha, om enkeles te noem.

Marlene van Niekerk se twee bundels onder bespreking is sterk emotiewe, inlewende beskrywings van die onderskeie kunswerke, gevolg deur gedetailleerde besinnings: oor die werk self, die ontstaan daarvan, oor die betrokke kunstenaar se agtergrond en habitus. Dikwels betrek die besinnings ook die liriese subjek se persoonlike konteks en geskiedenis.

Beide kunstenaars het teen die agtergrond van oorlog gewerk: Coorte met die oorlog rondom die Spaanse troonopvolging in die nabyheid en

Gesant van die mispels. Gedigte by skilderye van Adriaen Coorte ca. 16591707.

Marlene van Niekerk. Human \& Rousseau, 2017. 63 pp. ISBN 978-0-7981-7655-2.

In die stille agterkamer. Gedigte by skilderye van Jan Mankes 1889-1920. Marlene van Niekerk. Human \& Rousseau, 2017. 67 pp. ISBN 978-0-7981-7654-5. DOI: dx.doi.org/10.17159/2309-9070/tvl.v.55i2.5295
Mankes met die Eerste Wêreldoorlog rondom hom. En beide het gewoon voortgegaan om kuns te skep, sonder om die geweld rondom hulle in hul werke te betrek. In die "Nawoord" tot In die stille agterkamer word Mankes se werk soos volg getipeer: "Die ingetoë werk van Mankes verteenwoordig één moontlike respons van kunstenaars op roerige tye: afsondering, tegniese inspanning, ' $n$ verlangsaamde maakproses en emosionele fokus. In sy werke word 
die teenstrydighede van sy tyd nie getematiseer of bevoorgrond nie, maar op 'n geordende wyse 'opgelos' via 'n aandagtige, skilderkunstige behandeling van die oppervlakke van alledaagse voorwerpe" (63).

Coorte se werke word weer in die Nawoord tot Gesant van die mispels beskryf as "beskeie en intiem. Die beskeidenheid betref nie net die onderwerpe niesteeds enkele eksemplare van groente of vrugte-maar ook skaal en materiaal. [...] Die werke boei deur die effek van miniaturisering en die vreemde, verstilde ligval oor geïsoleerde vorms teen 'n sterk verdonkerde agtergrond. Coorte slaag daarin om deur koel, presiese en niksverklappende vakmanskap die geheimsinnige outonomie van gewone dinge sigbaar te maak" (59). In die laaste gedig in hierdie bundel stel die liriese subjek ook: "Met 'n jaloers-ekfrastiese / gebaar hou ek jou voor as meester van beson- / derhede te midde van misbaar" (Gesant 54).

Vanuit beskouings van en besinnings oor die "alledaagse voorwerpe" en "gewone dinge" kom telkens vernuftige, aangrypende gedigte met sterk slotte tot stand. Vergelyk die gedig gebaseer op Coorte se skildery Een Wan Li-kom met aardbeien (1704) waarin verskeie kreatiewe prosesse mekaar oorvleuel:

Jou skilderslig het niks te make met son, met skreef of hort of venstergat, dit is nie van die dag gemaak, of in warmte gedoop, maar gedep met iets beskouliks, of, eerder, daarin vasgehou-'n koel omarming van iets volledig onomarmbaars, die pleroma van bewoning, die wonder- baarlike daarvan-'n kommetjie met vrugte volgestapel, rustend op 'n blad, met daarin vervat ' $n$ onlangse geskiedenis van gebuk-

kend tuur en soek, 'n arm laag tussen die ranke ingestrek, drie vingerpunte saamgerond in sinlike verwagting, oё met die kleur van rypheid ingeprent. Altyd daal die skyn gestadig uit die regter- of die linkerkant, maar is nie nader te bepaal, en tref die aarbeie

en porselein, die twee gestipte kalwers van die ree, met ' $n$ bestendige gelatenheid. Sonderling verwant, dié gloed, aan die soort vlag wat digters onder aandrang van hul bloed onsigbaar na die ondermaanse dradie stok en tou en lap wat hulle altoos sprokkel uit die puin, en elke keer weer insteek, vastrap, hys, ontbondel, opdat dit skoksgewyse uit die kreukel val en in die weedom stil bly hang,' $n$ vlinder pas ontpop, en kiertsregop, die klein wit vrede van die woordwildeaarbeiblom.

Mankes se skildery Parelhoen (1917) word weer uiters klank- en beeldryk vertolk, met die liriese subjek se konteks asook die eietydse politiek wat saampraat:

Hierdie skilder, poelpetaat, wat in jou kop 'n bergtop sien, in jou pluim 'n wildernis waarop hy nag en sterre kwas-hy wis nie wat

hy alles aan die doene was. Vanoggend toe ek, aangedaan deur jass-musiek van Dollar

Brand, jou gly-pas repeteer, sien ek skielik Leeukop, kry ek die reuk van reën op bloekomblare, hoor ek vingertikke op 'n gellingkan en toe ' $n$ warm hael van 
munte

in my bors, klippe, slae, oproerskote.

Dis één olifantgeraaskal, daardie vaderland

van my, één gelieg en raserny, ongestelp

sedert die bloed en magtelose hulpgeroep van slawe. Droewe Kaap van dooie siele waar net die andersmaak van saksofone ons ooit kan lei oor striemende verskille; heem van landgenote, weggevlugtes, hul wat sleutels sonder deure in die bosak dra, en altyd hierdie ballingklanke sal herken-in Dublin, Frankfurt, Amsterdam-

die blues wat bresse in die borsbeen

slaan, 'n walvispluim verlange uit die keelgat

blaas. Woza Mntwana! Karnuffel daardie oliekan-

met-polkadots-orkes, laat loop jou jazz

hier in my gellingdrom, die geel van jou simbale

oor my kis. Die kans is, ek word eendag

hierdie kant begrawe met jou triole op my steen, 'n broeis-kreoolse aardetaal van windblou wildehoender-lelle en 'n klein, regop hanekam van troos.
Die Nederlandse vertalings lewer dikwels nuwe nuanses op, vergelyk die twee gedigweergawes van Coorte se Vier abrikozen op een stenen tafel (1698), die variasies op die Eurydice-beeld in die gedig oor Stilleven met asperges (1699), "kyker" teenoor "kunstliefhebber" in die gedig oor Druiventros (1705), "'n grypsel ou tabak" teenoor "pruimtabak" in die gedig oor Vanitasstilleven in een nis (1688) en "speel" teenoor "sluizen" in die gedig oor Mankes se skildery Lijster op tak (1910), om enkele variante aan te toon. 'n Vergelyking tussen die Afrikaanse en Nederlandse tekste verlang ' $\mathrm{n}$ afsonderlike studie.

Beide bundels bevestig Marlene van Niekerk se statuur as uiters fynsinnige waarnemer en briljante vertolker van intieme beelde.

Human \& Rousseau kan gelukgewens word met hul pragtige uitgawes van die bundels.

\section{Henning Pieterse}

PieterseHJ@ufs.ac.za

Universiteit van die Vrystaat

Bloemfontein 